\title{
Corrigendum
}

\section{Deep Brain Stimulation, Authenticity and Value-CORRIGENDUM}

\author{
JONATHAN PUGH, HANNAH MASLEN, and JULIAN SAVULESCU
}

https:/ / doi.org/10.1017/S0963180117000147, Published by Cambridge University Press, 22 September 2017.

The funding information was not included in the article by Pugh et al. ${ }^{1}$ in the October 2017 issue of Cambridge Quarterly of Healthcare Ethics. The acknowledgment should read as follows:

This work was supported by the Wellcome Trust [WT203195/Z/16/Z]; [WT104848/Z/14/Z].

This information has been updated in the original article online.

\section{Note}

1. Pugh J, Maslen H, Savulescu J. Deep brain stimulation, Authenticity and value. Cambridge Quarterly of Healthcare Ethics 2017;26(4):640-57. https:/ / doi.org/10.1017/S0963180117000147. 